ARTIGOS

\title{
OS DISCURSOS DA DIVULGAÇÃO CIENTÍfICA: Um estudo de revistas especializadas em divulgar ciência para o público leigo
}

Copyright (C) 2013 SBPjor / Associação Brasileira de Pesquisadores em Jornalismo

\author{
ELIZABETH MORAES GONÇALVES \\ Universidade Metodista de São Paulo
}

RESUMO - Os discursos de Divulgação Científica na mídia constituem uma forma de discurso público que integra os aspectos sociais, culturais, ideológicos, políticos e econômicos relacionados com o contexto de tempo e espaço. Com subsídio teórico da Análise de Discurso, o texto apresenta modos distintos de divulgar ciência para o público leigo em três revistas de Divulgação Científica: Scientific American Brasil, Pesquisa Fapesp e Superinteressante. O compromisso editorial de cada uma das revistas com seus leitores está na base da construção discursiva. A Scientific American Brasil busca nas explicações de muitas fontes e abordagem técnica a proximidade com a ciência. A Revista Pesquisa FAPESP recorta a temática para o contexto nacional e busca as explicações também de cientistas brasileiros e explora o gênero reportagem jornalística, por meio do qual o jornalista especializado atua. A revista Superinteressante tem um contrato mais distante da cientificidade, livre dos jargões científicos, usando gírias e comparações próprias do linguajar do seu público.

Palavras-chave: Comunicação. Divulgação Científica. Discurso.

\section{EL DISCURSO DE DIVULGACIÓN CIENTÍFICA: un estudio de revistas especializadas en divulgar la ciencia al público lego}

RESUMEN - Los discursos de divulgación científica en los medios de comunicación son una forma de discurso público que integra aspectos sociales, culturales, ideológicos y políticos relacionados con el contexto de tiempo y espacio. Con apoyo teórico del Análisis del discurso, el texto presenta modos distintos de presentar la ciencia al público lego en tres revistas de divulgación científica: Scientific American Brasil, Pesquisa FAPESP (Fundación de Apoyo a la Investigación del Estado de São Paulo) y Superinteressante. El compromiso editorial de cada una de las revistas con sus lectores es la base de la construcción discursiva. La Scientific American Brasil, busca en las explicaciones de muchas fuentes y el enfoque técnico, la proximidad con la ciencia. La revista Pesquisa FAPESP, que selecciona la temática del contexto brasileño con explicaciones de científicos brasileños, explora el género del reportaje periodístico, por medio del cual actúa el periodista especializado. La revista Superinteressante tiene un contrato más distante de la cientificidad y, libre de la jerga científica, utiliza un lenguaje informal propio de su público.

Palabras clave: Comunicación. Divulgación científica. Discurso. 


\title{
SCIENTIFIC DISSEMINATION DISCOURSE: a study of specialized magazines disseminating science to lay audiences
}

\begin{abstract}
Scientific Dissemination enunciations in the media are form of public discourse that integrates social, cultural, ideological and political aspects related to their spatial and temporal context. With theoretical support of Discourse Analysis the article presents distinct modes of disseminating science to the lay audience found in three magazines disseminating scientific knowledge: the Scientific American Brazil, Pesquisa Fapesp and Superinteressante. The editorial commitment of each one of these magazines to its readers is the basis of the discursive construction. The Scientific American Brazil draws on many sources for its explanations using a technical approach and close proximity to the patterns of science. The Pesquisa FAPESP magazine addresses the themes in their Brazilian context, uses Brazilian scientists as sources and adopts the journalistic reporting genre with exts by specislized journalists. Superinteressante magazine has a has a more distant commitment to science with exts free from using, instead, catch phrases, slang and types of comparison appropriate the language of its audience.

Keywords: Communication. Scientific dissemination. Speech.
\end{abstract}

\section{A CIÊNCIA PARA O PÚBLICO LEIGO}

O surgimento da atividade de Divulgação Científica no Brasil não tem uma data concreta, pois há divergências entre os pesquisadores devido a diferentes concepções existentes: enquanto alguns consideram a Divulgação Científica intrínseca à própria produção da ciência, acompanhando o seu desenvolvimento (MACEDO, 2002; MASSARANI; MOREIRA, 2004), outros marcam que a atividade surgiu no século XVII, como uma necessidade da ciência moderna, por considerar que a educação das pessoas deve incluir todo o conhecimento do funcionamento do universo (REIS, 2001; CALVO HERNANDO, 2006).

As primeiras iniciativas de divulgar dados de pesquisas científicas são registradas em livros, conferências e em demonstrações de experimentos para um público restrito. Segundo Macedo (2002), a divulgação para um público mais amplo tem início no século XVI, com os primeiros periódicos científicos. Reis (2001), no entanto, questiona sobre o alcance daquele público e propõe que

Representativo desse esforço de espalhar a ciência seria o livro de Bernier le Bovier de Fontenelle "Entretiens sur la pluralitè des mondes", publicado em 1686. [...] Poderíamos então considerar Fontenelle como popularizador da ciência se ele escrevia apenas para a aristocracia, que era a classe interessada nesse 
tipo de conhecimento, e manifestava até a convicção de que o conhecimento científico devia constituir o privilégio da elite? (REIS, 2001).

A criação da imprensa Régia no Brasil ocorreu em 1810, com a chegada da Corte portuguesa. Desse modo, tornou-se possível a impressão de textos e manuais voltados para a educação científica, "enquanto passaram a circular os primeiros periódicos, com artigos e notícias relacionados à ciência" (BRASILIANA, 2009).

$\mathrm{Na}$ atualidade, a divulgação dos avanços da ciência e da tecnologia pela mídia tem propiciado ao público leigo oportunidades de construir seu conhecimento em um segmento que tradicionalmente que se caracteriza por ser muito complexo e quase inacessível. Embora a atividade de divulgar ciência não seja atual, é nas últimas décadas, sobretudo no Brasil, que se concentra o grande crescimento da mídia nesse segmento, seja no formato de jornais e revistas, seja no formato de programas televisivos e, mais recentemente, em sítios da WEB vinculados a universidades e institutos de pesquisa.

Por isso, a Divulgação Científica tem sido uma atividade cada vez mais exigida na sociedade atual, haja vista a relevância do seu papel na construção da cidadania. $O$ estudo desse segmento, na perspectiva discursiva, leva-nos a entender que não se trata de uma atividade neutra, nem de um jornalismo totalmente objetivo, de forma que revistas com perfis editoriais diferenciados oferecem tratamentos distintos às temáticas abordadas e relacionam-se de formas distintas com o seu público. Pode-se, assim, propor que se trata de diferentes discursos da Divulgação Científica, ou de diferentes gêneros ou subgêneros no mesmo segmento midiático.

Nessa perspectiva, selecionamos para este estudo três revistas de Divulgação Científica significativas nesse segmento, porém com perfis e públicos distintos. No entanto, o espaço deste artigo não permite um detalhamento da análise do material selecionado, por isso apresentamos uma síntese dos resultados obtidos de análises que foram realizadas em um projeto de pesquisa desenvolvido durante dois anos.

Em relação às revistas, a Scientific American Brasil caracterizase como sofisticada, para atender a um público que tem interesses específicos pela ciência e pela evolução tecnológica. Já a revista Pesquisa FAPESP, por estar vinculada à Instituição de fomento à pesquisa do Estado de São Paulo e distanciada da relação comercial da mídia, trata a ciência e o público também com uma ênfase muito técnica. A Superinteressante, por sua vez, com perfil totalmente comercial, atinge o público jovem, que busca na Divulgação Científica seu aspecto fantástico ou mesmo lúdico. 
Dessa forma, a discussão da relação entre ciência, mídia especializada e sociedade torna-se relevante por se entender que esse tipo de publicação deve cumprir uma função social indispensável de entender, explicar e interagir com o leitor, assegurando às pessoas a consciência de sua cidadania e a participação nos destinos da nação e do mundo.

Os estudos da argumentação, das marcas do convencimento e/ou da persuasão em análises comparativas no jornalismo são muito frequentes, no sentido de apontar a subjetividade das relações eu-tu estabelecidas nos textos da mídia. Porém, quando se trata dos textos da Divulgação Científica, há uma visão estereotipada de uma necessária objetividade em busca da verdade característica da ciência, e os estudos restringem-se a identificar as marcas dessa objetividade. Entendemos, portanto, que os estudos da Divulgação Científica fazem parte da máquina midiática, seja no que se refere ao vínculo com um contrato de comunicação estabelecido entre o suporte e o leitor, seja pela relação comercial e/ou institucional do veículo, seja na relação que une o divulgador de ciência e o público pretendido.

Embora se denomine genericamente de "leigo" o público não cientista, alvo das publicações midiáticas de divulgação da ciência, há diferentes níveis de conhecimento científico ou diferentes formas de relacionamento desse público com esse conhecimento. Nesse sentido, não se pode se dirigir da mesma forma a um público da revista Scientific American - sofisticado, que domina um vocabulário mais técnico e que se interessa profissionalmente pelas informações oriundas da evolução da ciência e da tecnologia - com o público da revista Superinteressante, que busca a novidade, o inédito, a face fantástica da informação científica. Da mesma forma, o vínculo da Revista Pesquisa FAPESP com a Instituição de pesquisa bem como o seu afastamento do perfil comercial determinam uma produção de Divulgação Científica diferenciada.

Além disso, as recentes reflexões teóricas sobre o discurso, sobretudo as desenvolvidas por Maingueneau e Charaudeau, enfatizando as formas de dizer, evidenciadas tanto pelo enunciado quanto pela enunciação, permitem-nos identificar o ethos do divulgador da ciência, conforme a imagem que se tem do público, e, consequentemente, conforme o contrato estabelecido entre a publicação e o seu público. Esse conhecimento sobre a melhor forma de relacionamento com o público resulta em revistas com perfis editoriais muito distintos, no sentido de atender às suas necessidades. Conforme Verón (2004), a preferência de um grupo de leitores por um determinado título depende, mais do que das propriedades discursivas desse título, de representações sociais dos 
próprios leitores. A bagagem cultural dos leitores, por exemplo, pode influenciar a sua escolha pelo consumo de um título em vez de outro.

Já Ferreira (2003, p. 269) observa que nesse contexto comercial "o tipo de discurso jornalístico obedece a uma tradição enquanto um ramo da produção cultural submetido, depois de algum tempo, às leis da concorrência. O contrato de leitura é forjado pela lei de mercado".

Neste estudo, as três revistas estudadas relacionam-se com o mercado de formas muito distintas, enquanto a Superinteressante, publicação da editora Abril, caracteriza-se como um produto altamente comercial, haja vista o fato de ter $50 \%$ de suas páginas reservadas aos anunciantes, a Scientific American Brasil tem uma média de apenas 10 anúncios em cada edição (anúncios de produtos e serviços culturais ou tecnológicos) e a Revista Pesquisa FAPESP dedica apenas as contracapas para a publicação de anúncios institucionais vinculados à própria Fundação.

\section{SOBRE AS REVISTAS}

A revista Scientific American Brasilé editada pela Duetto Editorial, editora Fundada em abril de 2001, como resultado da associação de duas importantes editoras brasileiras: a Ediouro Publicações, com sede no Rio de Janeiro; e a Editora Segmento, com sede em São Paulo.

Além disso, a Scientific American publicou seu primeiro número em 28 de Abril de 1845 e desde então vem ocupando um espaço significativo no mercado editorial de publicações especializadas em ciência, cumprindo seu papel de Divulgação Científica. Segundo informações de seu site, em 1845, o editor Rufus Porter enfatizava sua crença na proposta da revista da seguinte forma: "(a publicação) irá reter sua excelência e valor quando outras tiverem sido esquecidas" (SCIENTIFIC, 2009).

Ao longo desse amplo período, a revista tem divulgado importantes descobertas científicas e invenções tecnológicas responsáveis pelo progresso da humanidade, tais como o telefone, a lâmpada incandescente, o raio $X$, a invenção do cinematógrafo de Lumière, a televisão, as viagens interplanetárias, a descoberta do nêutron e a fragmentação do átomo, o desenvolvimento do transistor, do computador, a fibra ótica e a descoberta do DNA.

Atualmente, a Scientific American Brasil faz parte de um pool internacional de publicações (editada em 20 países, 16 idiomas), dentre eles: Estados Unidos, Canadá, Alemanha, França, Itália, Espanha, Polônia 
e Japão. O Brasil é o vigésimo país a editar essa revista (SCIENTIFIC, 2009).

A revista Pesquisa FAPESP, criada em 1999, é produzida pela FAPESP (Fundação de Amparo à Pesquisa do Estado de São Paulo). Com periodicidade mensal, a publicação é vendida em bancas e por assinatura (a comercialização teve início em 2002) e é aberta à publicidade. De acordo com a apresentação no site, a revista "é resultado da evolução editorial do informativo Notícias FAPESP. Lançado em agosto de 1995, o informativo começou com uma distribuição gratuita para os pesquisadores paulistas, gestores da política nacional de ciência e tecnologia e jornalistas. Quatro ano mais tarde virou revista" (REVISTA PESQUISA FAPESP, 2009).

A Pesquisa FAPESP tem tiragem de 35.800 exemplares e tem seu foco na divulgação da produção científica e tecnológica nacional. Segundo informações do site, a revista "funciona como um polo de contato e reconhecimento contínuo dos pesquisadores brasileiros e como referência indispensável para as editorias de ciência e tecnologia dos veículos de comunicação nacionais" (REVISTA PESQUISA FAPESP, 2009).

A Pesquisa FAPESP trabalha, exclusivamente, com textos jornalísticos, nas categorias informativa (notícias, reportagens e entrevistas) e opinativa (artigo e resenha). Há espaço, também, para o gênero literário, com a publicação de um conto em cada edição. Além disso, desenhos, infográficos, ilustrações e fotografias de qualidade acompanham as matérias e, harmonicamente, compõem a informação.

No segmento de Divulgação Científica, a Superinteressante, publicação da Editora Abril, define-se como jovem e atrativa: "Ela inova nas pautas com abordagens criativas para os temas que todos estão discutindo e antecipa tendências, contando para o leitor, em primeiríssima mão, aquilo que vem por aí" (SUPERINTERESSANTE, 2009). Ainda segundo informações do site da publicação, pesquisas elaboradas pelo Marplan (órgão que efetua pesquisas regulares de mídia e de mercado) e pelo IVC (Índice de Verificação de Circulação) de 2007 fornecem dados sobre o perfil dos leitores e a circulação da revista, conforme segue: $52 \%$ têm entre 20 e 39 anos, predominantemente do sexo masculino (54\%), situados, na sua maioria (83\%) entre as classes A e B. A revista registra um número de 2.614.000 leitores e uma tiragem de 405.417 exemplares por edição, sendo a região Sudeste do país responsável por 49\% dessa circulação, seguida da região sul, com $22 \%$. 


\section{DIVULGAÇÃO CIENTÍFICA E SUBJETIVIDADE DA LINGUAGEM}

A Análise de Discurso da linha francesa, sobretudo os recentes estudos de Maingueneau e Charaudeau sobre o ethos, cenografia e contrato de comunicação constituem os referenciais teóricos que propiciam elementos para a identificação das características discursivas das revistas de Divulgação Científica que compõem o corpus deste estudo: edições de 2009 e 2010 das revistas Scientific American Brasil, Revista Pesquisa FAPESP e Superinteressante. Trata-se de uma pesquisa qualitativa, com abordagem descritiva, desenvolvida a partir da revisão de literatura e observação do corpus selecionado.

Ao defender que o discurso é o lugar no qual se articula o poder, a Análise de Discurso de linha francesa forneceu-nos o apoio teórico para observarmos o comportamento das revistas ao tratar as temáticas selecionadas e a maneira como cada uma delas se relaciona com o público que visa atingir.

Nas matérias informativas, vários elementos linguísticos permitem-nos analisar o discurso jornalístico como dotado de intencionalidade, em que o "sujeito passa a ocupar uma posição privilegiada, e a linguagem passa a ser considerada o lugar da constituição da subjetividade" (BRANDÃO, 2004, p. 45). No âmbito da Divulgação Científica, o estudo da seleção das matérias que compõem a publicação revela essa relação entre texto e contexto, ou seja, entre os conteúdos veiculados, as formas como são veiculados, e o contexto de produção determinante. Vários fatores externos ao texto contribuem para a seleção do material publicado e para a forma como o assunto é tratado, marcando uma íntima relação entre o discurso e suas condições de produção, pois, "o método de análise de linguagem instituído pela análise de discurso [...] incide justamente na relação da linguagem com as condições (a situação) em que ela se produz, ou seja, seu contexto sócio-histórico-cultural" (ORLANDI, 1989, p. 12).

Parte-se, portanto, do texto linguístico, observando, por exemplo, as diferentes maneiras de relatar opiniões, ou seja, as formas utilizadas pelo autor para introduzir, em seu texto, a fala de outro. Nessa perspectiva, Marcuschi (1991) desenvolve um estudo dos verbos introdutores de opinião, comumente utilizados no jornalismo para introduzir a fala do outro, sendo alguns mais referenciais e outros mais carregados de avaliação. Segundo o autor (1991, p. 72), “a opinião é introduzida com algum verbo que antecipa o caráter geral da opinião relatada", ou seja, esses verbos atuam de forma seletiva sobre os 
conteúdos, imprimindo-Ihes uma intencionalidade interpretativa com características ideológicas, revelando a percepção do narrador sobre o conteúdo do fato observado ou do discurso relatado.

Na análise textual a partir das marcas linguísticas, assim como os verbos anteriormente citados, os operadores argumentativos, elementos gramaticais, como preposições e conjunções, igualmente atuam no sentido de levar à identificação da formação discursiva a que os textos estão vinculados. Tais elementos no texto têm a função de orientar para determinada leitura, valorizando, por exemplo, uma informação em detrimento de outra, como é caso da conjunção adversativa "mas" que, ao ser inserida em um contexto, carrega, além do sentido de adversidade, também uma valorização, por parte do locutor, da proposição ou do elemento com o qual está mais diretamente vinculado.

Os operadores atuam, portanto, como ferramenta essencial para detectar a argumentatividade presente no discurso jornalístico, especialmente porque os autores desse discurso trabalham com técnicas que lhes dão a aparência de isenção e neutralidade, técnicas como a do "jornalismo declaratório", na qual o jornalista "fala" com base em suas fontes, ou com o apoio de dados, aparentemente, irrefutáveis.

Desse modo, há diversos modos de dizer e, consequentemente, diversas formas de se interpretar o que é dito. Todo falante ou escrevente tem uma intencionalidade, explícita em maior ou menor grau pela escolha lexical, pelo ordenamento das frases, pela composição do paratexto, pelo uso de operadores argumentativos. Segundo Koch (1984, p. 24), "toda atividade de interpretação presente no cotidiano da linguagem fundamenta-se na suposição de que quem fala tem certas intenções ao comunicar-se. Compreender uma enunciação é, nesse sentido, apreender essas intenções".

A abordagem da Análise do discurso, especificamente no caso do discurso da Divulgação Científica que constitui objeto deste estudo, considera a multiplicidade das vozes do discurso, proposta por Bakhtin (1981) que, nesse contexto, deixa de ser uma abstração já que efetivamente se analisa um discurso unificado por seu meio de transmissão, mas para o qual contribuem diretamente diferentes sujeitos: alguns com orientações, em princípio, comuns e outros com orientações eventualmente conflitantes às do primeiro. Brandão, por sua vez, retoma o pensamento de Michel Foucault sobre as relações de poder no âmbito da linguagem, visto que, para Brandão (2004, p. 31): "[...] o discurso é o espaço em que saber e poder se articulam, pois quem fala, fala de algum lugar, a partir de um direito reconhecido 
institucionalmente. Esse discurso, que passa por verdadeiro, que veicula saber (o saber institucional), é gerador de poder".

Conforme Leibruder (2002, p. 230), "a Divulgação Científica é uma prática eminentemente heterogênea, na medida em que incorpora no seu fio discursivo tanto elementos provenientes daquele que the serve de fonte - o discurso científico - quanto daquele que pretende atingir - o discurso jornalístico". A autoridade da voz do cientista está sempre presente, seja pela sua própria narração ou descrição (quando é o autor do texto da Divulgação Científica), seja pela voz do jornalista e de outras fontes citadas no texto. Nas publicações que analisamos, temos a Scientific American Brasil mais próxima da linguagem científica, a Revista Pesquisa FAPESP, mais próxima da linguagem jornalística reflexiva e a Superinteressante mais próxima de um jornalismo mais factual ou imediatista.

Dessa forma, estabelece-se um jogo de imagens entre os atores envolvidos nesse processo comunicacional: a imagem que o autor faz do seu leitor, a imagem que o autor julga ter junto ao seu leitor, a imagem que o leitor faz de si próprio e da publicação que escolhe ler. Segundo Pêcheux ${ }^{1}$ (2010), nos processos discursivos existe uma série de formações imaginárias que designam o lugar que os interlocutores se atribuem cada um a si e ao outro e também a imagem que eles fazem de seu próprio lugar e do lugar do outro. É com base nesse funcionamento discursivo que Amossy (2005, p. 142) reflete:

\begin{abstract}
A construção discursiva de uma imagem de si é suscetível de conferir ao orador sua autoridade, isto é, o poder de influir nas opiniões e de modelar atitudes. Essa ótica corrobora as perspectivas da pragmática que considera que a fala possui um poder e produz um efeito sobre o alocutário na troca verbal - em outros termos, que o discurso permite (inter)agir. Para todas as abordagens que valorizam a eficácia da fala, o ethos não é somente uma postura que manifesta o pertencimento a um grupo dominante, ele é uma imagem de si construída no discurso que influencia opiniões e atitudes.
\end{abstract}

No caso das revistas analisadas, essas imagens determinam o posicionamento assumido pela publicação frente aos fatos relatados e pelo divulgador de ciência em diferentes momentos.

\title{
3 ETHOS E O DIVULGADOR DE CIÊNCIA
}

A prática da análise do discurso pressupõe que se considerem as manifestações enunciativas como resultantes da interação entre os interlocutores. Orlandi (2001, p. 117) lembra que "nas construções 
estão as marcas com que me represento ao meu interlocutor", porém, "a antecipação do que o outro vai pensar é constitutiva do discurso, a nível das formações imaginárias".

A análise, portanto, não deve se limitar às manifestações linguísticas ou ao texto que é tomado como elemento empírico primeiro para se observar, como pretendemos neste trabalho, as opções de construção das cenas da enunciação e as posições do locutor e sua relação com o interlocutor:

\begin{abstract}
A linguagem enquanto discurso não constitui um universo de signos que serve apenas como instrumento de comunicação ou suporte de pensamento; a linguagem enquanto discurso é interação, e um modo de produção social; ela não é neutra, inocente e nem natural, por isso o lugar privilegiado de manifestação da ideologia (BRANDÃO, 2004, p. 11).
\end{abstract}

Além disso, a relação que se estabelece entre a instância de produção e a de recepção é marcada pela intencionalidade, ou seja, há uma intenção em se comunicar de determinada maneira e de produzir determinados efeitos, considerando o perfil da publicação e o perfil do leitor que se tem em mente, porém não se pode garantir a concretização tais efeitos de sentido, uma vez que

[...] todo título ou artigo jornalístico, toda descrição de um apresentador de noticiário televisivo (NT) ou radiofônico, toda explicação de um jornalista especializado, estarão carregados de efeitos possíveis e só uma parte deles corresponderá às intenções conscientes destes, e outra parte - não necessariamente a mesma será reconstruída pelo receptor (CHARAUDEAU, 2003, p. 26).

No contexto específico da Divulgação Científica, Leibruder (2002) salienta que a seleção lexical e o modo narrativo utilizado, a inserção de elementos valorativos em maior ou menor escala, dependem do contexto enunciativo no qual o conteúdo se insere, não apenas do "meio através do qual o artigo será veiculado, mas essencialmente do interlocutor a quem este se dirige" (LEIBRUDER, 2002, p. 236).

A inserção do autor no texto é fato inevitável. Ao se considerar a impossibilidade da produção de um texto neutro, isento das posições do seu autor, evidencia-se que as marcas da sua subjetividade podem ser encontradas em maior ou menor nível, dependendo das características e dos objetivos da obra. No contexto da Divulgação Científica, cujo texto deve ser entendido como uma produção textual não apenas como uma tradução, entende-se que tais marcas são evidenciadas de diferentes formas, dependendo das características de cada publicação e de cada divulgador de ciência. 
O enunciador é, então, percebido no texto, não por meio de elementos costumeiramente atribuídos à identificação do autor, como o uso da primeira pessoa do singular ou de termos avaliativos, mas pelo tom utilizado ao demonstrar os fatos ou relatar as ideias, muitas vezes inovadoras do conhecimento a que se refere. Portanto, ele é percebido pela forma de dizer, de se posicionar no ato da enunciação. Estamos, nesse sentido, frente à noção de Ethos desenvolvida por Maingueneau (2008), apoiando-se nas teorias de Oswald Ducrot:

\begin{abstract}
Não se trata de afirmações elogiosas que o orador pode fazer a respeito de sua pessoa no conteúdo do seu discurso, afirmações que correm o risco, ao contrário, de chocar o auditório, mas da aparência que Ihe conferem a cadência, a entonação, calorosa ou severa, a escolha das palavras, dos argumentos... Em minha terminologia, direi que o ethos está associado a L, o locutor enquanto tal: é na medida em que é fonte da enunciação que ele se vê revestido de certos caracteres que, em consequência, tornam essa enunciação aceitável ou refutável (MAINGUENEAU, 2008, p. 59).
\end{abstract}

No contexto da Divulgação Científica, a relação que se estabelece entre o divulgador (jornalista ou cientista), por meio do veículo e o público leitor, revela um ethos diferenciado, considerando-se a especificidade do conteúdo veiculado e os objetivos envolvidos nesse processo comunicativo, caracterizado como um campo entre o discurso científico e o jornalístico, ora mais próximo do primeiro, ora do segundo. Portanto, quem divulga os avanços da ciência e da tecnologia deve estar/ ser ciente de que sua tarefa ultrapassa os limites da pura informação, às vezes entendida, equivocadamente, como mera tradução.

Nesse sentido, Maingueneau (2008) explica que o ethos do enunciador revela-se ao leitor por meio da conjunção de diferentes elementos: a) o ethos pré-discursivo, o que se espera desse enunciador, considerando o estilo da publicação, seu público e seus objetivos comerciais; b) o ethos discursivo, ou o tom que assume ao elaborar o texto (ethos mostrado), além de "fragmentos do texto em que o enunciador evoca sua própria enunciação (ethos dito): diretamente [...] ou indiretamente, por exemplo, por meio de metáforas ou de alusões a outras cenas de fala" (MAINGUENEAU, 2008, p. 71).

Caracterizado como um texto que necessita de apelos persuasivos para garantir a participação de seus leitores, o texto de Divulgação Científica lança mão de estratégias diferenciadas de composição enunciativa ou de cenas de enunciação, conforme a terminologia de Maingueneau (2008, p. 70), nas quais o ethos é parte constituinte: "Por meio do ethos, o destinatário está, de fato, 
convocado a um lugar, inscrito na cena de enunciação que o texto implica. Essa "cena de enunciação" compõe-se de três cenas, que propus chamar "cena englobante", "cena genérica" e "cenografia"'. No caso deste estudo, a cena englobante é a que caracteriza os textos como pertencentes ao âmbito da Divulgação Científica, pelo objetivo claro que evidenciam; a cena genérica, como o próprio nome indicia, está vinculada à Divulgação Científica em revista especializada (poderia ser outro tipo de revista ou outro veículo, o que caracterizaria outro gênero de Divulgação Científica); e a cenografia depende de cada reportagem, ou seja, em cada uma delas, selecionam-se recursos diferentes de composição, de apresentação e, consequentemente, de inserção do ethos do divulgador de ciência.

\section{OS MÚLTIPLOS DISCURSOS DA DIVULGAÇÃO CIENTÍFICA}

Partimos do pressuposto de que não existe apenas um discurso de Divulgação Científica. Desse modo, as publicações são responsáveis por construir diferentes discursos, conforme as características dos veículos e do público a que se destinam, haja vista que as manifestações enunciativas são resultantes da interação entre os interlocutores, ideologicamente marcadas pela linguagem.

A esse respeito, Charaudeau (2003) apresenta a mídia como uma máquina produtora de signos que se originam na parte da atividade humana dedicada a construir sentido social (lógica semiológica), que está em relação com o contexto econômico, pois todo órgão informativo atua como uma empresa, cuja finalidade consiste na fabricação de um produto definido pelo lugar que ocupa no mercado de intercâmbio de bens de consumo (lógica econômica). Portanto, na perspectiva discursiva, o enunciado não deve ser abordado isoladamente do seu contexto enunciativo, que envolve desde as condições de produção até as possíveis condições de recepção, passando, evidentemente pelo conteúdo a ser veiculado e pelo impacto que as informações científicas e/ou tecnológicas possam ter para a sociedade.

Especificamente na revista Superinteressante há um movimento importante entre o jornalista e o cientista - enquanto, por um lado, o jornalista encontra na fala do cientista a validação e o reforço da sua fala, assume-se como um fiador da veracidade dos fatos, garantindo que o leitor possa incorporar-se ao texto, com segurança em relação aos dados apresentados, ou, conforme Maingueneau (2008, p. 53): "a legitimação do enunciado não passa somente pela articulação de proposições, ela 
é habitada pela evidência de uma corporalidade que se dá no próprio movimento da leitura".

A falta de domínio dos termos técnicos e até dos elementos julgados primários paraa compreensão dos fatos científicos possivelmente explicam a posição assumida pela revista Superinteressante, que mostra um divulgador de ciência com um ethos da parceria, da amizade, da conivência com o leitor. Quem divulga ciência e tecnologia nessa publicação é um jornalista que se situa ao lado do leitor, como alguém confiável, que sabe do que está falando, por isso fala com autoridade, ainda que precise sempre recorrer à citação das falas do pesquisador para reforçar o que está sendo exposto.

No que se refere às fontes, não há uma preocupação com os dados concretos sobre todo o processo de construção e elaboração da pesquisa, com seus erros, acertos e dificuldades, a metodologia e os procedimentos metodológicos. Na prática, o que interessa, na visão equivocada de alguns jornalistas, são apenas os resultados e sua aplicação prática, em prejuízo da compreensão do contexto da produção da ciência e da tecnologia. Trata-se de uma visão pragmática que reforça o processo de mitificação da ciência. O pesquisador é citado como alguém que domina o conhecimento e, assim, ratifica ou reforça a ideia exposta pelo jornalista.

A Superintessante procura ainda construir uma cenografia adequada a cada conteúdo e válida estritamente para aquele contexto, buscando nos estereótipos sociais, elementos capazes de persuadir o destinatário a fazer uma leitura atenta e a se interessar pelo conteúdo veiculado. Trata-se de outro recurso amplamente explorado pela publicação, no intuito de aproximar-se do seu leitor: a linguagem da Divulgação Científica, nesse caso, é acrescida da característica lúdica.

Os números de assinantes, de leitores e de circulação, divulgados pelo site do grupo Abril, são suficientes para marcar o perfil mercadológico da revista Superinteressante. Trata-se de vender ciência para um público já conquistado ao longo dos anos, ainda que sejam dados científicos distantes da Divulgação Científica pretendida pelos pesquisadores, que possam promover a inserção, de fato, do progresso da ciência na sociedade, e que o cidadão sinta-se parte desse processo. O uso de expressões populares e de gírias também ajuda a construir um discurso de Divulgação Científica muito peculiar, na tentativa de se aproximar do jovem, público da revista. Por um lado, trata-se de uma percepção comercial de manter o contato com esse público; por outro, pode significar uma superficialidade na divulgação dos dados científicos, 
como se o jovem não fosse capaz de apreender um significado mais complexo, mais próximo dos próprios fatos da ciência.

Diferentemente da Superinteressante, a revista Scientific American Brasil apresenta um divulgador de ciência com um ethos muito distinto. Muitas vezes o papel é assumido pelo próprio pesquisador e o distanciamento dos fatos relatados e também do público a que se dirige marcam um posicionamento mais aprofundado ou elitista, em relação ao conhecimento divulgado. A análise da linguagem da Scientific American Brasil mostra que o modo como os resultados da pesquisa científica figuram na publicação está ainda muito distante de trazer o saber científico brasileiro para a agenda de discussões no país. Trata-se de uma revista de Divulgação Científica para um público bastante específico, estudioso das temáticas científicas e tecnológicas, interessado nas inovações, pesquisadores acadêmicos ou leitores bem preparados para textos complexos. Se por um lado não se trata de comunicação entre os pares, também não chega a atingir o cidadão comum, leigo em ciência ou não participante de uma cultura científica.

O grupo seleto de cientistas brasileiros que figuram na capa da Scientific American Brasil representa o sucesso do desenvolvimento científico do país e a crença no seu crescimento, principalmente por intermédio de parcerias nacionais e estrangeiras, embora em comparação com os dados dos investimentos internacionais em ciência e tecnologia mostre uma grande distância nos investimentos destinados à CT\&l, apesar das reiteradas promessas de duplicar esses recursos para 2\% do PIB nacional. A publicação da revista Scientific American no Brasil, contudo, tem representado um elemento positivo de fazer a ciência nacional figurar, lado a lado, entre resultados de pesquisas mundialmente reverenciadas.

Por ser uma revista norte-americana, a ênfase na ciência desenvolvida nos Estados Unidos é recorrente, como se observa no levantamento quantitativo elaborado por Gonçalves (2008). O número de matérias brasileiras que tem destaque na publicação não chega a ultrapassar os 30\% a que a revista se propôs em 2002, quando iniciou sua edição brasileira. Grande parte das matérias é escrita pelo próprio editor e outra parte também significativa pelos próprios pesquisadores. Nesse caso, o discurso científico predomina sobre o jornalístico, exatamente o contrário da revista Pesquisa FAPESP, que procura, por meio exclusivamente de reportagens, fazer o discurso jornalístico predominar sobre o científico, mantendo uma linguagem se não acessível ao público jovem, mas pelo menos ao público adulto em geral, particularmente o 
universitário e pesquisador.

O divulgador de ciência tem a tarefa de construir um texto que revele consistência em relação aos dados apresentados, porém que seja acessível ao leitor. Na Revista Pesquisa FAPESP, observamos que essa preocupação é constante em todas as etapas, desde a seleção de termos que compõem o texto até a composição e exposição gráfica da matéria. Nesse sentido, a busca de explicação dos termos técnicos, na forma de exemplos, metáforas ou comparações é ricamente explorada.

Mesmo com o propósito de ser objetivo, o jornalista, ao produzir as reportagens da Revista Pesquisa FAPESP, faz uma angulação ao tratar a temática em pauta, evidenciando o ethos do divulgador de ciência, sua posição frente ao fato abordado e frente ao público a que se destina. Além disso, as cenografias construídas em cada reportagem marcam que o texto de Divulgação Científica encontra na construção das cenas da enunciação (segundo a terminologia de Maingueneau) um recurso para atrair o leitor e prendê-lo ao texto, recurso explorado pelo jornalista no gênero reportagem, qualquer que seja o segmento explorado.

A Revista Pesquisa FAPESP tem ainda a função de trazer ao público os resultados dos investimentos que o país tem feito em ciência e tecnologia ou, mais diretamente, dos investimentos que a própria FAPESP tem feito no pesquisador nacional. Por isso, a ênfase do conteúdo estar na pesquisa brasileira. A revista tem primado por um texto claro e bem elaborado com imagens ricas e significativas, priorizando a participação do pesquisador brasileiro em grandes temas internacionais. A visão crítica do jornalista e da revista é evidenciada pela escolha das falas das fontes que têm espaço na publicação.

\section{CONSIDERAÇÕES FINAIS}

As publicações de Divulgação Científica que analisamos neste trabalho assumem comportamentos distintos ao selecionarem a temática, ao assumirem posicionamentos e ao se relacionarem com o público. Enquanto a Scientific American Brasil adota a postura da "cientificidade", por meio da fala das muitas fontes consultadas, a Superinteressante situa-se no nível da "conversação", utiliza recursos (como o inédito e o fantástico) que levam o leitor a se interessar pelo conteúdo que é lido; já a Pesquisa FAPESP tece o texto jornalístico, com ênfase na fala do jornalista e apoio nas falas das fontes consultadas. Nesse sentido, comportam-se como todos os meios de comunicação, que segundo Charaudeau (2003) são somente um espelho deformante, 
embora sejam responsáveis por uma parcela ampliada, simplificada ou estereotipada do mundo.

O compromisso editorial de cada uma das revistas com seus leitores está na base da construção discursiva. A Scientific American Brasil busca nas explicações de muitas fontes e abordagem técnica a proximidade com a ciência. A Revista Pesquisa FAPESP recorta a temática para o contexto nacional e busca as explicações também de cientistas brasileiros e explora o gênero reportagem jornalística, por meio do qual o jornalista especializado tem grande autonomia no tratamento dos fatos. A revista Superinteressante, por sua vez, tem um contrato mais distante da cientificidade, livre dos jargões científicos, usando gírias e comparações próprias do linguajar do seu público.

O que interessa para ser divulgado na Superinteressante, como o próprio nome sugere, é a parte atrativa da ciência, aquilo que faz parte do dia a dia do leitor: a ciência que ajuda a desvendar os crimes, a controlar a ansiedade do cotidiano e a salvar os oceanos. Esses são temas que permeiam a vida do homem e onde os avanços da ciência podem ser pragmaticamente vistos, ainda que todo o processo para se chegar aos resultados apresentados tenham sido longos.

Em suas atrativas páginas cheias de ilustrações, infográficos e jogos de palavras, a revista Superinteressante revela uma imagem do seu leitor - jovem, ousado, interessado no inédito e surpreendente, mas que exige muita rapidez e objetividade. Desse modo, o jornalista, divulgador de ciência, nessa publicação tem uma postura, um comportamento que revela seu ethos de fiador, de parceiro do seu leitor, aquele que aprendeu antes para poder ensinar com segurança. Essa segurança e confiabilidade, contudo, é assegurada pela fala do cientista que vem a legitimar a voz do jornalista. Nesse jogo de imagens - do enunciador e do coenunciador - processa-se o que Maingueneau (2008) denomina de ethos pré-discursivo: o leitor da Superinteressante sabe o que esperar da revista e esta, por sua vez, apresenta os elementos necessários para corresponder às exigências desse leitor.

No caso analisado, a revista norte-americana tem um histórico de mais de 150 anos, divulgando resultados de pesquisas e inovações tecnológicas responsáveis por mudanças significativas na vida do homem moderno, o que lhe garante credibilidade, de tal forma que o saber ali veiculado incorpora esse valor e destaca-se dos demais. Mesmo assim, é importante observar que o discurso de Divulgação Científica dessa publicação apresenta-se muito distante do grande público. Embora haja uma preocupação em explicar, definir, organizar os dados para 
divulgar de forma clara e precisa, ainda é abundante o uso de jargões, de linguagem impermeável, acessível a poucos que detêm o poder da informação científica como pré-requisito para aprender mais. Assim, perpetua-se o ciclo de que quem sabe mais pode saber mais ainda.

\section{NOTAS}

A data (2010) refere-se à obra consultada. A teoria de Pêcheux sobre a Análise Automática do Discurso é de 1969.

\section{REFERÊNCIAS}

AMOSSY, Ruth (Org). Imagens de si no discurso. São Paulo: Contexto, 2005. BAKHTIN, Mikhail. Marxismo e Filosofia de Linguagem. Trad. Bras. São Paulo: Hucitec, 1981 (original russo: 1929).

BRANDÃO, Helena H. Nagamine. Introdução à análise do discurso. Campinas: Unicamp, 2004.

BRASILIANA, A Divulgação Científica no Brasil. Disponível em http://www. museudavida.fiocruz.br/brasiliana/cgi/cgilua.exe/sys/start.htm?sid=14. Acesso: 4 Out. 2009.

CALVO Hernando, Manuel. La divulgación científica y los desafios del nuevos siglo. Disponível em <http:// www.jornalismocientifico.com.br/jornalismocientifico/ artigos/divulgacao_cientifica/artigol.php> Acesso: 28 Fev. 2006.

CHARAUDEAU, Patrick. El discurso de la información: la construcción del espejo social. Barcelona: Gedisa editorial, 2003.

FERREIRA, Giovandro Marcus. Contribuições da Análise do Discurso ao Estudo de Jornalismo. In FRANÇA, Vera [et al.] (Org.) Livro do XI Compôs 2002: Estudos de comunicação. Porto Alegre; Sulina, 2003.

GONÇALVES, Elizabeth Moraes. Divulgação Científica Brasileira: um diagnóstico da Revista Scientific American Brasil. Contemporânea - revista de Comunicação e Cultura, v. 6, p.1-15, 2008.

KOCH, I. V. Argumentação e Linguagem. São Paulo: Cortez, 1984.

LEIBRUDER, Ana Paula. Discurso de Divulgação Científica. In: BRANDÃO, Helena Nagamine. Gêneros do Discurso na Escola. $3^{a}$ ed. São Paulo: Cortez, 2002.

MACEDO, Mônica Gonçalves. Do texto ao hipertexto: argumentação e legibilidade nos discursos da divulgação científica. Tese de Doutorado. PósCom Umesp, 2002.

MAINGUENEAU, Dominique. Cenas da enunciação. São Paulo: Parábola Editorial, 2008.

MASSARANI, Luisa; MOREIRA, Ildeu de Castro. Divulgación de la ciencia: perspectivas históricas e dilemas permanentes. In: Quark $n^{\circ} 32$, abril-junho de 2004. Disponível em: <http://www.imim.es/quark>. Acesso: 18 Mar. 
MARCUSCHI, Luiz Antonio. A ação dos verbos introdutores de opinião. In INTERCOM - Revista Brasileira de Comunicação, ano XIV, nº 64, São Paulo, Janeiro/Julho, 1991.

ORLANDI, Eni P. Discurso e Texto - formulação e circulação dos sentidos. Campinas: Pontes, 2001.

ORLANDI, Eni Pulcinelli; GUIMARÃES, Eduardo; TARALLO, Fernando. Vozes e Contrastes - Discurso na cidade e no campo. São Paulo: Cortez, 1989.

PÊCHEUX, Michel. Análise automática do discurso (AAD-69). In: GADET, F.; HAK, T.(orgs). Por uma análise automática do discurso: uma introdução à obra de Michel Pêcheux. Campinas: Unicamp, 2010.

REIS, José. O que é divulgação científica [on line]. Disponível em <URL: http://www.eca.usp.br/nucleos/njr/divulg.htm> Acesso: 18 Nov. 2001.

REVISTA PESQUISA FAPESP. Quem somos. Disponível em: http://www. revistapesquisa.FAPESP.br/?art=31 85\&bd=2\&pg=1. Acesso: 4 Out. de 2009.

SCIENTIFIC American Brasil. Disponível em < http://www2.uol.com.br/ sciam/artigos/>. Acesso: 20 Abr. 2009.

SUPERINTERESSANTE. Disponível em http://publicidade.abril.com.br/homes. php?MARCA=44. Acesso: 11 Mai. 2009.

VERÓN, Eliseo. Fragmentos de um tecido. São Leopoldo: Unisinos, 2004.

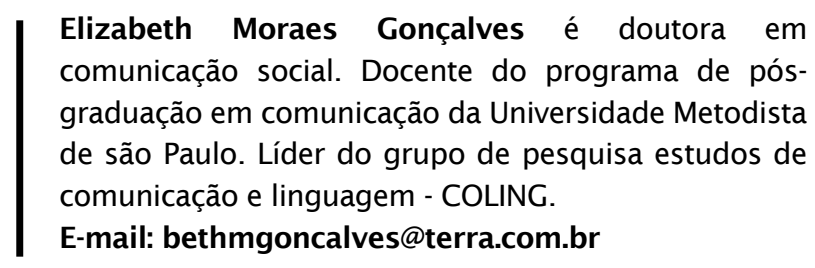

RECEBIDO EM: 04/03/2012 | ACEITO EM: 20/10/2013 